\title{
Toll-Like Receptor Agonists Modulate Galectin Gene Expression in Goat Blood
}

\author{
Kingsley Ekwemalor \\ Department of Applied Science and Technology \\ 1601 E. Market Street, Greensboro, NC, 27411 \\ E-mail: kaekwema@aggies.ncat.edu \\ Emmanuel Asiamah \\ Department of Applied Science and Technology \\ 1601 E. Market Street, Greensboro, NC, 27411 \\ E-mail: ekasiama@aggies.ncat.edu
}

Eboghoye ElukaOkoludoh

Department of Applied Science and Technology

1601 E. Market Street, Greensboro, NC, 27411

E-mail: eoeluka@aggies.ncat.edu

Bertha Osei

Department of Animal Sciences

1601 E. Market Street, Greensboro, NC, 27411

E-mail: bosei@ncat.edu

Dr. Sarah Adjei-Fremah

Department of Animal Sciences

1601 E. Market Street, Greensboro, NC, 27411

E-mail: sadjeifr@ncat.edu 


\author{
Dr. Mulumebet Worku (Corresponding author) \\ Department of Animal Sciences \\ 1601 E. Market Street, Greensboro, NC, 27411 \\ E-mail: worku@ncat.edu
}

Received: August 2, 2018 Accepted: September 25, 2018 Published: September 29, 2018

Doi: 10.5296/jab.v6i2.13462ＵRL: http://doi.org/10.5296/jab.v6i2.13462

\begin{abstract}
Pathogenesis and lack of effective therapeutics pose a threat to animal and public health. Recognition of pathogen-associated molecular patterns (PAMPS) by Toll-like receptors is associated with gene activation. Galectins are sugar-binding proteins that play a role in pathogen-recognition and immune modulation. The objective of this study was to investigate the effect of different TLR agonists on galectin gene expression and secretion in goat blood. Blood was collected from the jugular vein of BoerXSpanish goats $(n=3)$. Blood was treated with $10 \mu \mathrm{g} / \mathrm{ml}$ Lipopolysaccharide, Peptidoglycan, $12.5 \mu \mathrm{g} / \mathrm{ml}$ of Polyinosinic-polycytidylic acid, $10 \mu \mathrm{g} / \mathrm{ml} \mathrm{CpG} \mathrm{ODN} \mathrm{(2216)} \mathrm{and} 10 \mu \mathrm{g} / \mathrm{ml} \mathrm{CpG} \mathrm{ODN} \mathrm{(2006)} \mathrm{or} \mathrm{PBS} \mathrm{control.} \mathrm{Secretion}$ of galectin-1, -3 and -9 was measured by ELISA. Expression of LGALS-1, -2, -3, -4, -7, -8, $-9,-11,-12,-14,-15,-16$ was assessed using real-time PCR. Beta-actin and GAPDH served as controls. Fold change in gene expression was calculated using the $2^{-\Delta \Delta \mathrm{Ct}}$ method. Data were analyzed using SAS 9.4 statistical analysis software $(p<0.05)$. Expression and secretion galectins was modulated by different PAMPS $(\mathrm{p}<0.05)$ and may have implications for design of therapeutics based on TLR agonists.
\end{abstract}

Keywords: Galectins, Goats, Pathogen-associated molecular pattern

\title{
1. Introduction
}

In recent years there has been an increase in disease-causing pathogens which affects animal production (Contreras et al., 2007; Jones et al., 2008). Gastrointestinal nematode parasite infection remains one of the main constraints to goat production. Goat pathogens include bacteria (such as E. coli, Staphylococcus), protozoa such as Coccidia (Gibbons, Love, Craig, \& Budke, 2016) and viruses (Bodjo et al., 2018; Contreras et al., 2007; Rinaldi, Veneziano, \& Cringoli, 2007). These pathogens have distinct PAMPS. The main function of the immune system is to distinguish between host cells and PAMPS. The immune system comprised of both innate and adaptive immunity has various mechanisms by which it eliminates or withstands the impact of external agents. The role of PRR that recognize PAMPS and DAMPS has been characterized as bridging innate immune, sensory systems for infectious agents and metabolic dangers to initiation of inflammation (X.-F. Yang, Yin, \& Wang, 2008).

Toll-like receptors play a critical role in initiating innate immune responses and modulating adaptive immunity, by recognizing conserved microbial molecular patterns (Kannaki, 
Shanmugam, \& Verma, 2011; Tourais-Esteves, Bernardet, Lacroix-Lamandé, Ferret-Bernard, $\&$ Laurent, 2008). These receptors are important in pathogen recognition by cells in the innate immune system and polarization of adaptive immunity (Werling, Piercy, \& Coffey, 2006). Previous studies have reported the expression of TLRs 1-10 in goats (Ekwemalor, Adjei-Fremah, Asiamah, \& Worku, 2018; Ekwemalor, Asiamah, \& Worku, 2016). Toll-like receptors are mainly localized in the plasma membrane. They recognize a variety of conserved microbial PAMPS and metabolic DAMPS and promote inflammatory gene expression (Sun et al., 2018). Specific binding of agonists to TLR's 3, 4, 5, 7, 8 and 9 leads to high levels of Th1-type cytokine production, whereas binding to TLR 1, 2 and 6 triggers the initiation of Th2-type immune responses (Pulendran, 2004). The PAMPS recognized by TLRs include lipids, lipoproteins, proteins, and nucleic acids derived from a wide range of microbes such as bacteria, viruses, parasites, and fungi (Akira, Uematsu, \& Takeuchi, 2006). Previous studies conducted by our research team looked at mushroom probiotics as a form of PAMP which activates goat immunity (Ekwemalor, 2015; Ekwemalor et al., 2016). The interaction between TLRs and other recognition receptors such as galectins has been reported (Deierborg \& Burguillos, 2015).

Galectins constitute a family of animal lectins defined by their affinity for $\beta$-galactoside-binding proteins, and a characteristic carbohydrate recognition domain (Cooper, 2002). Galectin gene expression is modulated during development, differentiation stages and under different physiological and pathological conditions (Chiariotti, Salvatore, Frunzio, \& Bruni, 2002). Galectins can serve as PAMPS, DAMPs, PRR as well as immunomodulators in the innate response to some infectious diseases (Sato, St-Pierre, Bhaumik, \& Nieminen, 2009). Recent studies have indicated their function as PRR that target oligosaccharides on the surface of bacteria, Protista, helminth pathogens and parasites (Vasta, 2012). An efficient immune system is essential for fighting pathogens. Galectin gene expression and secretion are part of an effective immune system needed to combat infection and control disease. They are also important in regulating inflammation. Immune challenge and several pathological conditions may lead to further activation and differentiation of immune cells, and modulate the expression and release of galectins to the extracellular space where they have autocrine and paracrine effects on immune regulation (Vasta, 2012). Pathogen-associated molecular patterns represent pathogen-specific sugars/lipoproteins or nucleic acids expressed as part of their life cycle (i.e., bacterial DNA as unmethylated repeats of dinucleotide $\mathrm{CpG}$, double-stranded (ds) or single-stranded (ss) RNA). Some of these PAMP's include lipopolysaccharide fraction of gram-negative bacteria, peptidoglycans from gram-positive bacteria, unmethylated bacterial DNA fragments, poly I:C (viral DNA), as well as glucans and proteins that are derived from the fungal cell wall serve as PAMPS (Ekwemalor, Asiamah, Osei, Ismail, \& Worku, 2017; Ekwemalor et al., 2016). The interaction of PAMPS with galectins has been reported (Sioud, Mobergslien, Boudabous, \& Fløisand, 2010; Thurston, Wandel, von Muhlinen, Foeglein, \& Randow, 2012). Upon binding to different pathogens, studies have shown that galectins can be modulated.

Galectins are expressed in blood, tissues, parasites and during pregnancy (Ashraf et al., 2018, Asiamah et al., 2018, Ekwemalor et al., 2018, Souza et al., 2018). Galectins are synthesized and stored in the cytoplasm, but upon infection-initiated tissue damage and following 
prolonged infection, cytosolic galectins are either passively released by dying cells or actively secreted by inflammatory activated cells through a non-classical pathway. Galectins released by immune cells can oligomerize and form lattices at the cell surface leading to activation of transmembrane signaling pathways that modulate immune cell functions such as cell adhesion and migration, T-cell apoptosis, and the Th1/Th2 cytokine balance (Rabinovich $\&$ Toscano, 2009). Galectins are also released into the extra-cellular environment under abnormal situations they may themselves constitute danger signals by exerting their activities on other cells, such as mast cells, induce degranulation and release of factors that represent the danger signals leading to induce immune modulation (Sato \& Nieminen, 2002). Galectins have also been identified in the abomasum of ruminants infected with Ostertagia ostertagi and Cooperia oncophora (R. W. Li, Hou, Li, \& Gasbarre, 2010). Once exported, galectins act as PRR, as well as immunomodulators (or cytokine-like modulators) in the innate response to some infectious diseases. Galectins are dominantly found in the lesions where pathogen-initiated tissue damage signals appear; this lectin family is also considered as potential DAMP candidates that orchestrate innate immune responses alongside the PAMP system. This study was undertaken to evaluate different TLR agonists on galectin gene expression gene expression and secretion in goat blood. Studies on the expression of galectins will help in the definition of the immune response to diverse pathogens with distinct glycomic profiles.

\section{Materials and Methods}

\subsection{Animals and Housing}

Three non-pregnant SpanishXBoer goats from North Carolina Agricultural and Technical State University Farm were used. Animals were clinically healthy and not under any treatment. All experiments were approved and performed according to the guiding principles for the Institutional Animal Care and Use Committee (IACUC ID: 15-006.0).

\subsection{Preparation of PAMPS}

Ten (10) $\mu \mathrm{g} / \mathrm{ml}$ of Escherichia Coli-derived Lipopolysaccharide (LPS) (Sigma-Aldrich St. Louis, Missouri), $10 \mu \mathrm{g} / \mathrm{ml}$ of Staphylococcus aureus-derived Peptidoglycan (PGN) (Sigma-Aldrich St. Louis, Missouri), $12.5 \mu \mathrm{g} / \mathrm{ml}$ of Polyinosinic-polycytidylic acid (poly I:C), a synthetic analog of double-stranded RNA (dsRNA), $10 \mu \mathrm{g} / \mathrm{ml} \mathrm{CpG} \mathrm{ODN} \mathrm{(2216)} \mathrm{class} \mathrm{A,} \mathrm{or}$ $10 \mu \mathrm{g} / \mathrm{ml} \mathrm{CpG} \mathrm{ODN} \mathrm{(2006)} \mathrm{class} \mathrm{B:} \mathrm{a} \mathrm{synthetic} \mathrm{oligonucleotide} \mathrm{that} \mathrm{contains} \mathrm{unmethylated.}$ All the reagents were prepared using endotoxin-free water. Phosphate buffered saline was prepared as described (Ekwemalor, 2015).

\subsection{Sample Collection and Stimulation of Blood With Different PAMPS}

Whole blood $(10 \mathrm{~mL})$ was collected from the jugular vein into tubes containing an anticoagulant. One milliliter $(1 \mathrm{~mL})$ of blood from three (3) nonpregnant goats was incubated with $10 \mu \mathrm{g} / \mathrm{mL}$ each of Escherichia coli-derived Lipopolysaccharide (LPS) (Sigma-Aldrich St. Louis, MO), Staphylococcus aureus-derived Peptidoglycan (PGN) (Sigma-Aldrich St. Louis, MO), CpG ODN (2216) class A, CpG ODN (2006) class B, or $12.5 \mu \mathrm{g} / \mathrm{mL}$ of poly I:C, Phosphate Buffer Saline (PBS) individually to assess the expression of galectin genes. Samples were incubated at $37{ }^{\circ} \mathrm{C}$, with $85 \%$ humidity and $5 \% \mathrm{CO}_{2}$ for 30 minutes. Samples incubated with PBS served as negative control. At the end of the incubation period, cells were centrifuged 
at $1700 \times \mathrm{g}$ at $4{ }^{\circ} \mathrm{C}$ for 5 minutes. The supernatant was collected, and TRIzol reagent was added to cell pellets and stored at $-20^{\circ} \mathrm{C}$ for RNA isolation.

\subsection{RNA Extraction}

Total RNA was isolated from whole blood using TRIzol (Molecular Research Centre, Inc. Cincinnati, OH) (Adjei-Fremah et al., 2018, Asiamah et al., 2016, Ekwemalor et al., 2017). The quantity and quality of RNA were measured using the ND-1000 UV/VIS Nanodrop (NanoDrop Technologies) spectrophotometer (260 $\mathrm{nm}$ and 260/280 $\mathrm{nm}$ respectively) (Asiamah et al., 2016).

\subsection{Real-time PCR}

Reverse transcription of RNA was performed using Oligo (dT) primers with two ug of the total RNA from each treatment group using a cDNA RETRO script Kit (Ambion Inc., Austin, TX) as previously described by Adjei-Fremah et al., 2016. The cDNA products were measured for purity and concentration using the Nanodrop spectrophotometer. Primers specific for galectins (Table 1) were designed using the NCBI Primer 3 tool (v. 0.4.0) and sequenced commercially by Eurofins Genomics (Louisville, KY). Each PCR reaction was performed in triplicates and normalized using the housekeeping gene Glyceraldehyde-3-Phosphate Dehydrogenase (GAPDH) and $\beta$-actin. Fold change in gene expression was calculated using the $2^{-\Delta \Delta C t}$ method (Livak \& Schmittgen, 2001). Fold change was set at a cut-off of 2 .

Table 1. Primer Sequences for Galectin Genes (LGALS) Used for Real-time PCR

\begin{tabular}{llll}
\hline Gene & Primer & Sequence & $\begin{array}{l}\text { Primer } \\
\text { Length (bp) }\end{array}$ \\
\hline LGALS-1 & Forward & TTCAACCCTCGTTTTGAAGC & 170 \\
& Reverse & GGCAGCTTGATGGTTAGGTC & \\
LGALS-2 & Forward & CATCGTGACCTTCGAGAACA & 219 \\
& Reverse & TGATCCCACATGAAGAGCAG & \\
LGALS-3 & Forward & TCCACTTTAACCCACGCTTC & 151 \\
& Reverse & TCAGGTTCAACCAGCACTTG & \\
LGALS-4 & Forward & AGCGAGCACATGAAGAGGTT & 163 \\
& Reverse & GCATGCTCATTTTCCTCTCC & \\
LGALS-7 & Forward & TCTACGTGAACCTGCTGTGC & 237 \\
& Reverse & ACCGGAAGTGGTGGTATTCA & \\
LGALS-8 & Forward & CAGCCTGGAGTACAAGCACA & 156 \\
& Reverse & ACCAAGGCCAGTGTTACAGG & \\
LGALS-9 & Forward & GTGCCCAGGCTTCCTACATA & 153 \\
& Reverse & GGTCGTTATAGCCGGTCTGA &
\end{tabular}




\begin{tabular}{llll}
\hline LGALS-11 & Forward & CGAACCCCTATCAGCAGTCT & 161 \\
& Reverse & TCCCTTCACCTTCAGCATTT & \\
LGALS-12 & Forward & GTGAACAAAAGAACCCCCGC & 171 \\
& Reverse & CTAAGCAGAGAGGGCGATGG & \\
LGALS-14 & Forward & ATTCCTGTTGCAGAAGTCTACCTGG & 252 \\
& Reverse & GAACATCTTCCACACGGTAGGGGT & \\
LGALS-15 & Forward & GCGACATTCCATTTCGTTTC & 188 \\
& Reverse & CTGGCAGATGGGCTTGTTAT & \\
LGALS-16 & Forward & TTGAGCTGCAGTTCTTGGTG & 158 \\
& Reverse & CGCCCCTTATAACGTATCCA & \\
\multirow{2}{*}{-actin } & Reverse & TCTTCCAGCCTTCCTTCCTG & 172 \\
& Forward & ACCGTGTTGGCGTAGAGGTC & \\
GAPDH & Reverse & CTCCATGGTGGTGAAGAC & 198 \\
& Forward & GTCTTCACCACCATGGAG & \\
LGALS-3bp & Reverse & CATCCGTCCCTTCTACCTGA & 220 \\
& Forward & CCAGGGAAGTCTGCAGTAGC & \\
\hline
\end{tabular}

\subsection{Determination of Plasma Protein Concentrations}

Plasma was extracted after treatment and analyzed for total protein concentration (Thermo Scientific Pierce, Rockford, IL) following the manufacturer's protocol (Ekwemalor et al., 2016) and (E. K. Asiamah et al., 2016). Secretion of Galectins and concentration was detected using anti-goat Galectin ELISA kits (ABclonal Biotechnology, Woburn, MA) following the manufacturer's protocol.

\subsection{Statistical Analysis}

Total Protein concentration and Galectin secretion were analyzed using PROC GLM in SAS version (SAS Institute, Cary, NC). A $p$-value of less than 0.05 was considered significant.

\section{Results}

\subsection{Effects of PAMPS on Galectin and Galectin Ligand Gene Expression}

There was a significant effect of treatment on RNA concentration $(\mathrm{p}<0.001)$. There was no difference in RNA concentration of pooled samples $(\mathrm{P}=0.0625)$. The fold change in goat LGALS in response to tested PAMPS is shown in Table 2. Expression of Galectin genes (LGALS) measured using real-time PCR was affected by treatment. Stimulation with poly I:C downregulated LGALS-1, -8, -9, -15 and upregulated LGALS-7, -14, -16. However, LGALS-2, $-4,-11$ and -12 were unchanged. Galectin-3 and its binding protein LGAL-3 binding-protein were unchanged. Stimulation with ODN 2006 downregulated LGALS-1, -8, $-9,11,-15$ and upregulated LGALS-2, -7, and -16. However, LGALS-4, -12 and 14 were 
unchanged. Both LGAL-3 and its receptor LGAL-3 binding-protein were unchanged. Stimulation with ODN 2216 downregulated LGALs-4, -7, -8, -11, -12 and up-regulated LGALS-1, -2, -14, and -15. However, LGAL-9 and -16 was unchanged. Galectin-3 was upregulated, and its receptor LGAL-3 binding-protein was downregulated. Stimulation with LPS downregulated LGALs-1, -4, -8, -12, and -15 up-regulated LGALS-2, -7, -11, -14 and -16. Both LGAL-3 and its receptor LGAL-3 binding-protein were downregulated. Galectin-9 was unchanged. Stimulation with PGN downregulated LGALS-1, -7, -8, - 9, and -12 up-regulated LGALS-3, -14 and -15. However, LGALS-2, -4, -11 and -16 were unchanged. Galectin-3 was upregulated, and its receptor LGAL-3 binding-protein was unchanged.

\subsection{Total Plasma Protein Concentration}

The average total plasma protein concentration in plasma was $84 \mu \mathrm{g} / \mu 1$. Treatment with PAMPS did not have a significant effect on total protein concentration $(64-87 \mu \mathrm{g} / \mu \mathrm{l})$. There was no significant difference in the total plasma concentration due to treatment when compared to the control $(p>0.7831)$. The plasma protein concentration remained within the range of health goats which is about $72-79 \mu \mathrm{g} / \mu \mathrm{l}$. The sample treated with poly I:C had the highest concentration of $90 \mu \mathrm{g} / \mathrm{ml}$ (Figure 1). There was no significant variation in total plasma concentration between animals.

Table 2. Fold change in goat LGALS

\begin{tabular}{llllll}
\hline & Treatment & & & \\
\cline { 2 - 5 } Galectins & POLY I:C & ODN 2006 & ODN 2216 & LPS & PGN \\
\hline LGALS-1 & -1.19 & -2.38 & 2.00 & -6.28 & -1.02 \\
LGALS-2 & 1.11 & 2.00 & 4.00 & 2.00 & 1.09 \\
LGALS-3 & 1.04 & 1.13 & 3.00 & -4.47 & 2.00 \\
LGALS-4 & 1.00 & 1.07 & -1.41 & -1.30 & 1.21 \\
LGALS-7 & 2.00 & 2.00 & -1.04 & 2.23 & -1.09 \\
LGALS-8 & -2.00 & -2.00 & -2.19 & -2.00 & -2.31 \\
LGALS-9 & -2.00 & -2.00 & 1.40 & 1.06 & -1.14 \\
LGALS-11 & 1.01 & -1.09 & -1.20 & 2.13 & 1.30 \\
LGALS-12 & 1.19 & 1.35 & -1.32 & -2.00 & -4.11 \\
LGALS-14 & 2.00 & 1.21 & 2.00 & 3.58 & 11.96 \\
LGALS-15 & -2.57 & -2.53 & 2.00 & -2.00 & 4.38 \\
LGALS-16 & 2.00 & 2.00 & 1.00 & 4.00 & 1.39 \\
LGALS-3pb & 1.00 & 1.35 & -2.00 & -1.22 & 1.08 \\
TIM-3 & 2.00 & 14.57 & 11.66 & 40.37 & 1.00 \\
\hline
\end{tabular}

Fold change $\geq 2$ is considered significant. 


\subsection{Secretion ad Modulation GAL-1, -3 and -9 in Plasma}

All GAL tested were secreted in plasma. However, there was variation in the concentration of each type. GAL-1 and -3 was detected in Nanogram per microliter (ng/ $\mu \mathrm{l})$, and GAL-9 was detected in Picogram per microliter $(\mathrm{pg} / \mu \mathrm{l})$ quantities. Exposure to PAMP's affected secretion of all GAL tested. Poly I:C affected the concentration of secreted GAL-1, 3, and 9 ( $p<0.001)$. Poly I:C increased the concentration of GAL-1 compared to control (PBS). Poly I:C reduced the concentration of GAL-3 and -9 (Figure 2). ODN 2006 affected the concentration of GAL-1, 3, and 9 ( $p<0.001$ ). ODN 2006 increased the concentration of GAL-1 and -3 compared to control (PBS). ODN 2006 decreased the concentration of GAL-9 (Figure 3). ODN 2216 affected the concentration of GAL-1, -3, and -9 ( $p<0.001)$. ODN 2006 increased the concentration of GAL-1, -3 and -9 (Figure 4). Lipopolysaccharide treatment affected the concentration of GAL-1, -3 , and $-9(\mathrm{p}<0.001)$. Treatment with LPS reduced the concentration of GAL-1 and -9 compared to control (PBS). LPS treatment increased the concentration of GAL-3 (Figure 5). Peptidoglycan treatment affected the concentration of GAL-1, -3 , and $-9(\mathrm{p}<0.001)$. Treatment with PGN reduced the concentration of GAL-1, -3 , and -9 (Figure 6).

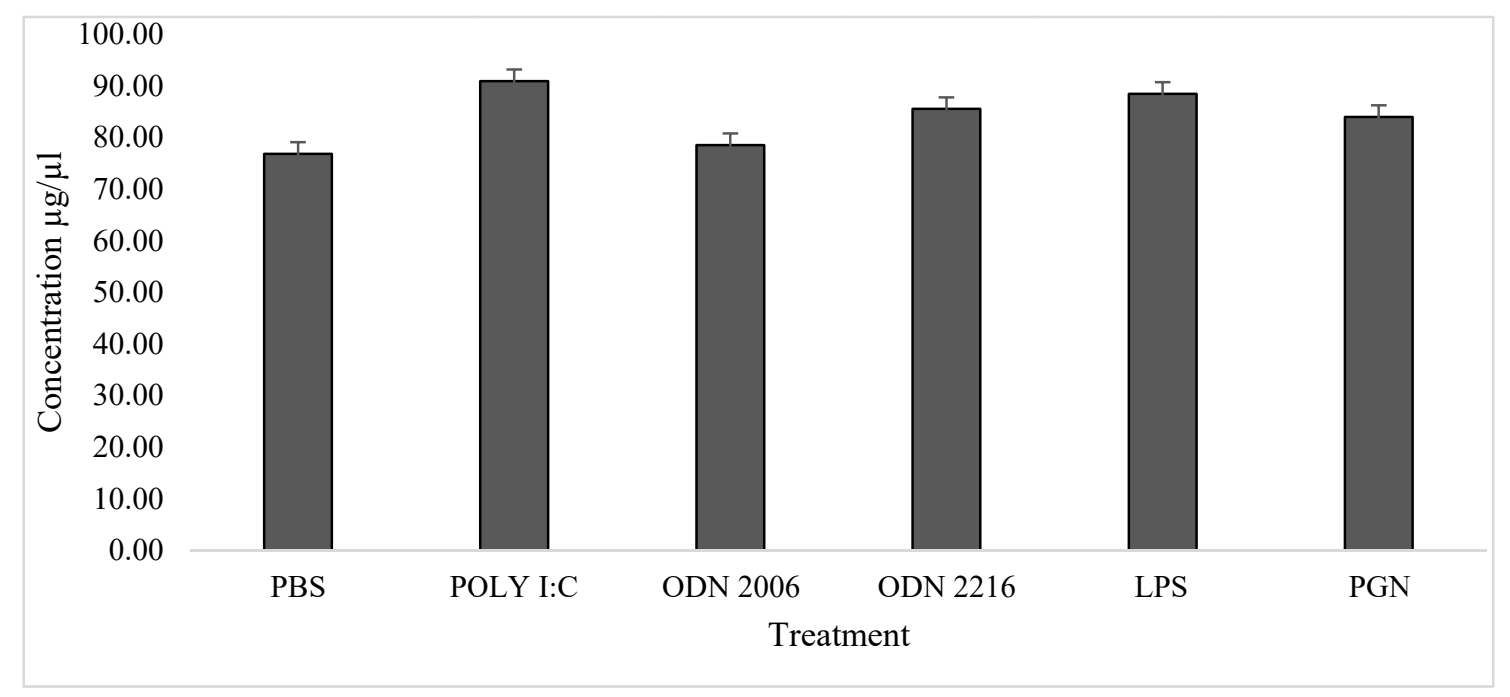

Figure 1. Average total protein concentration measured in plasma following treatments of PBS, poly I:C, ODN 2006, ODN 2216, LPS and PGN 


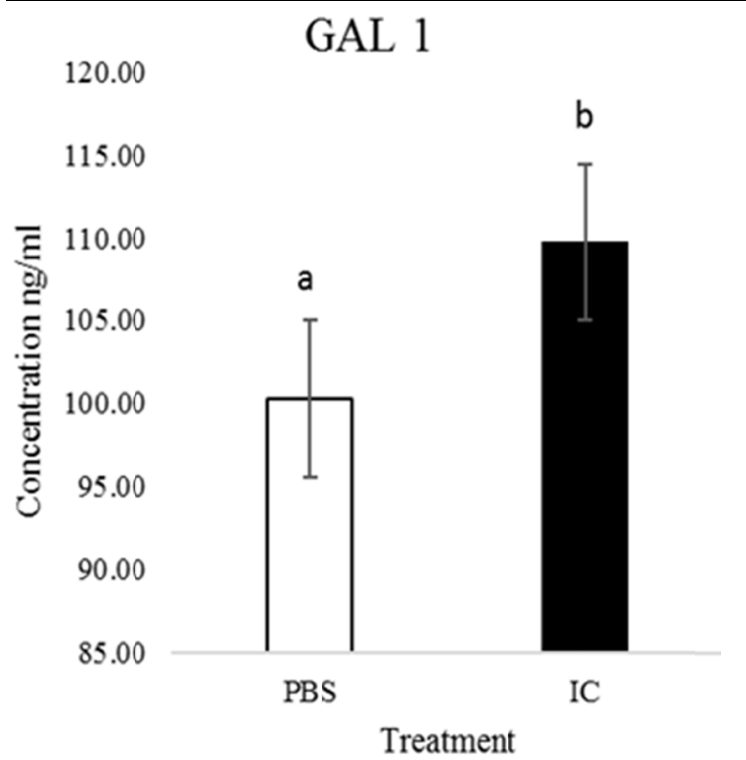

A)

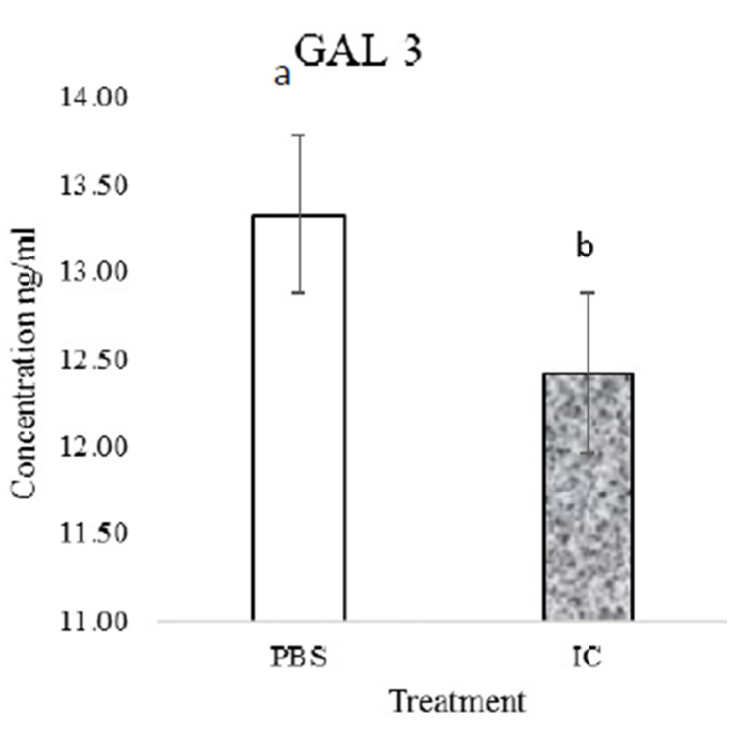

B)

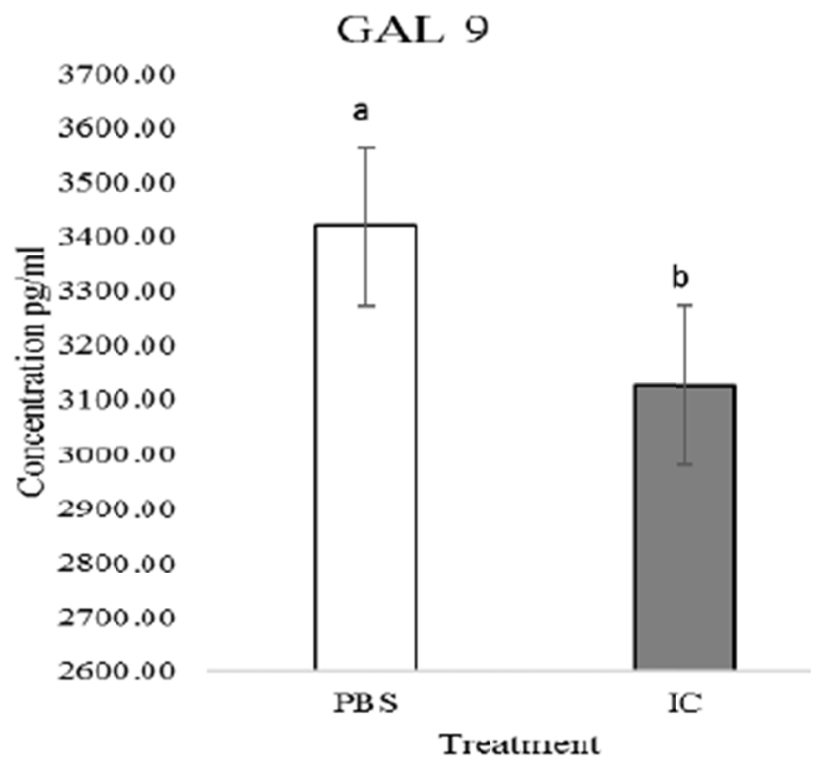

C)

Figure 2. Effect of Poly I:C on the concentrations of secreted GAL-1, -3, and -9 in plasma A) GAL1, (B) GAL3, (C) GAL9. Means with the same letter are not significantly different from each other. $(p<0.005)$. Error lines represent \pm standard deviation of the mean. 


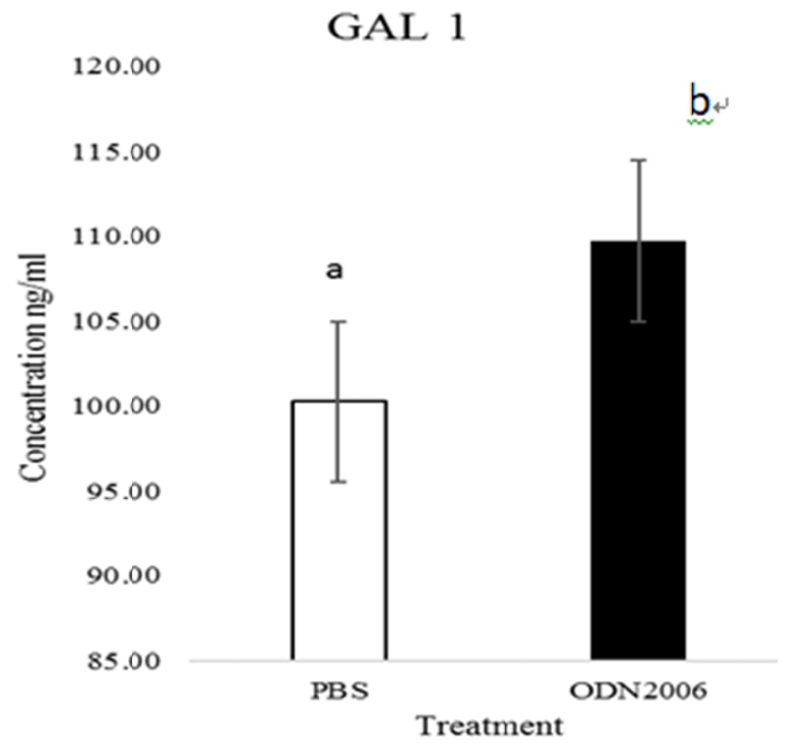

GAL 3

A)

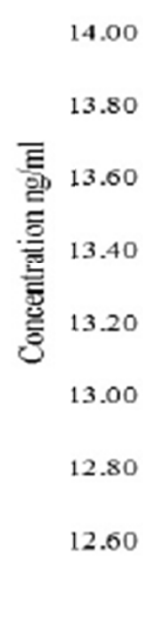

12.60 b

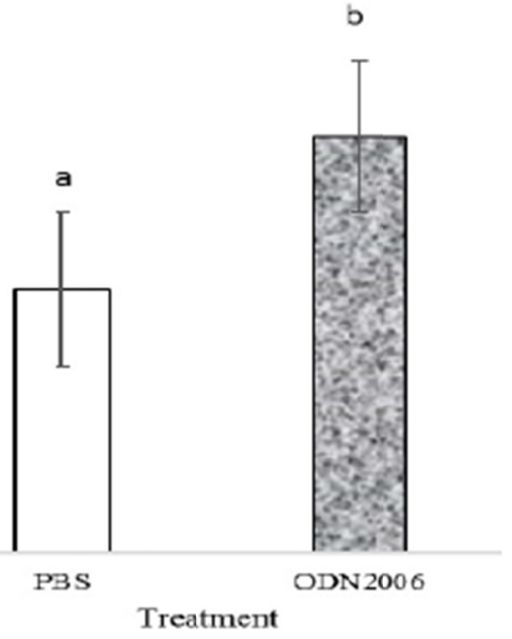

B)

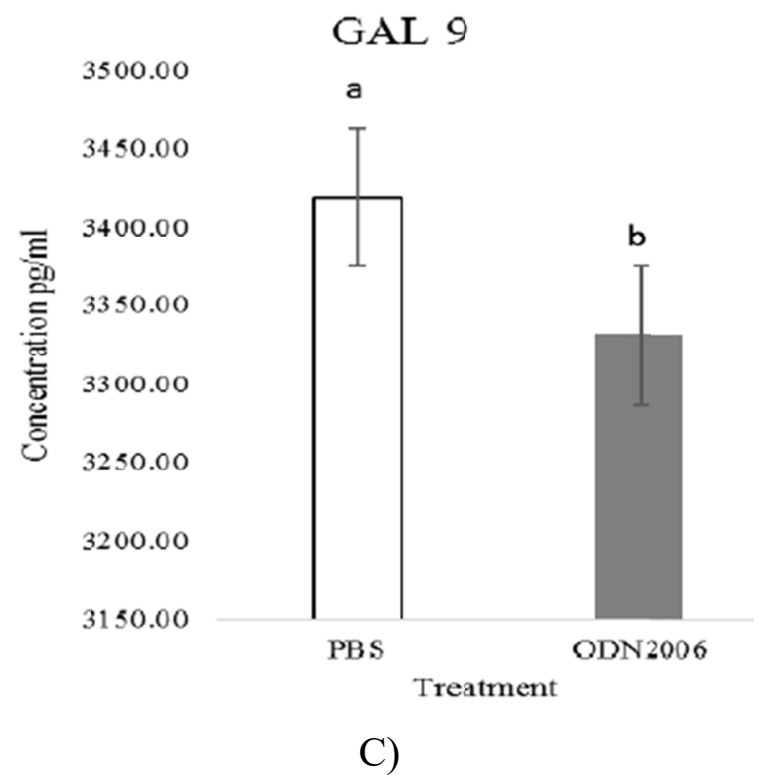

Figure 3. Effect of ODN 2006 on the concentrations of GAL-1, -3, and -9 measured in plasma

(A) GAL1, (B) GAL3, (C)GAL9. Means with the same letter are not significantly different from each other $(\mathrm{p}<0.005)$. Error lines represent \pm standard deviation of the mean 


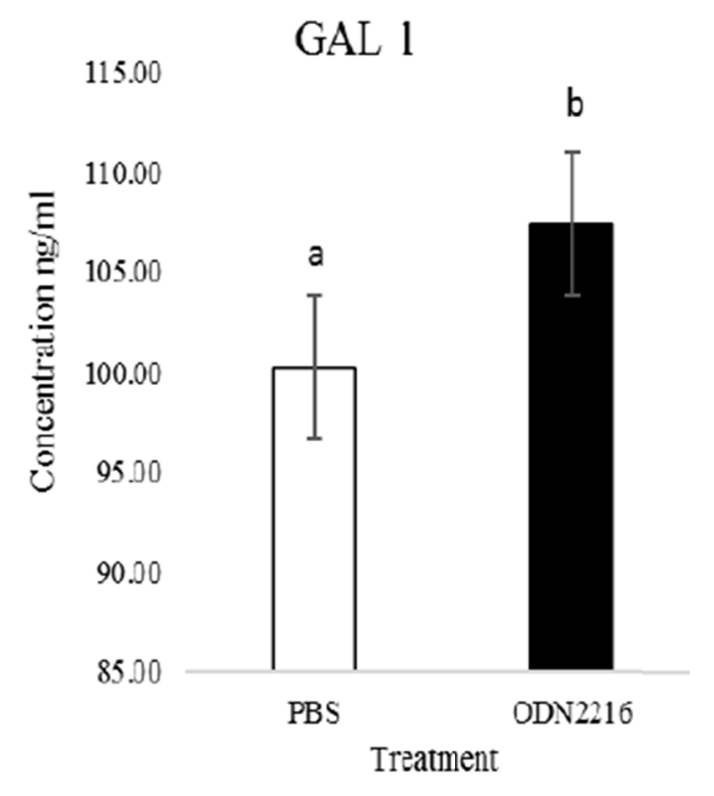

A)

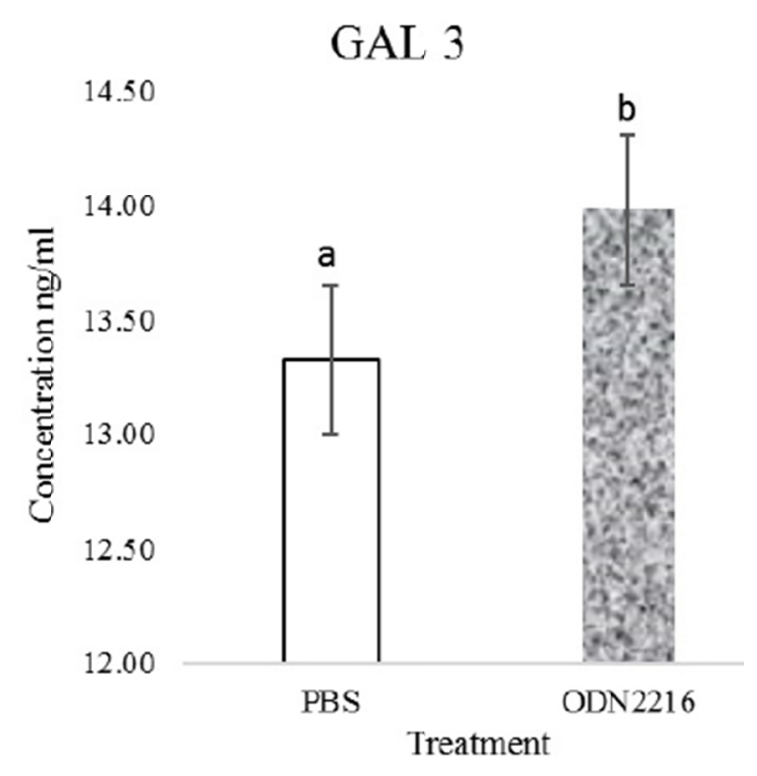

B)

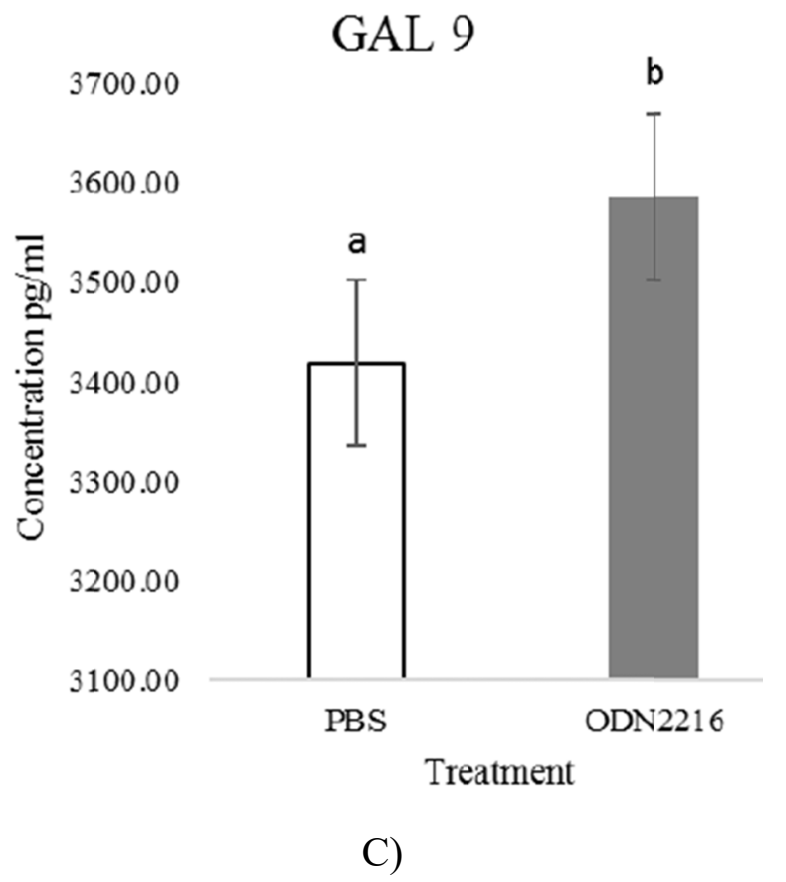

Figure 4. Effect of ODN 2216 on the concentrations of GAL-1, -3, and -9 measured in plasma

(A) GAL1, (B) GAL3, (C) GAL9. Means with the same letter are not significantly different from each other $(p<0.005)$. Error lines represent \pm standard deviation of the mean. 


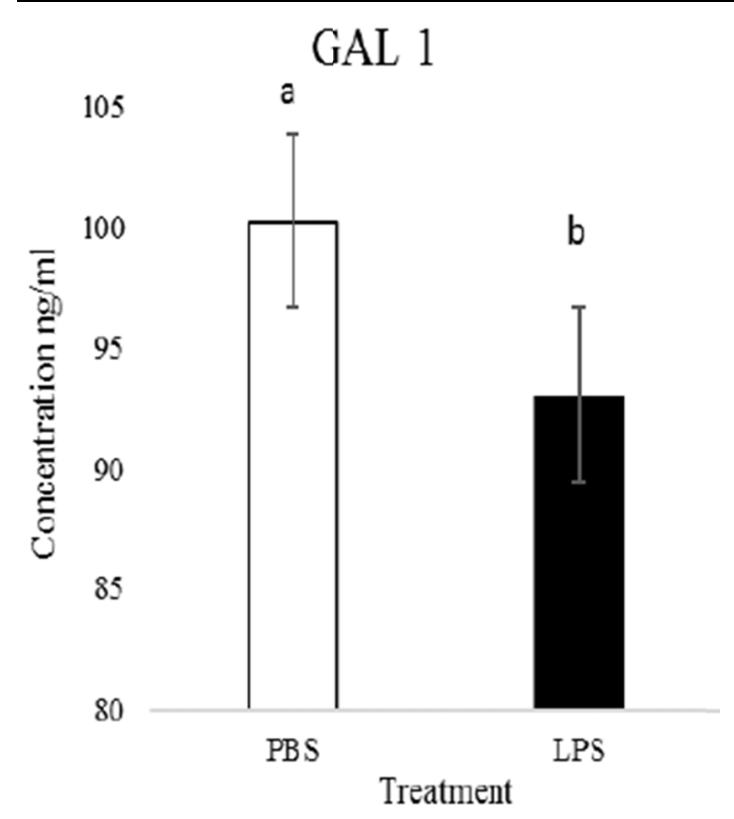

A)
GAL 3

14.2

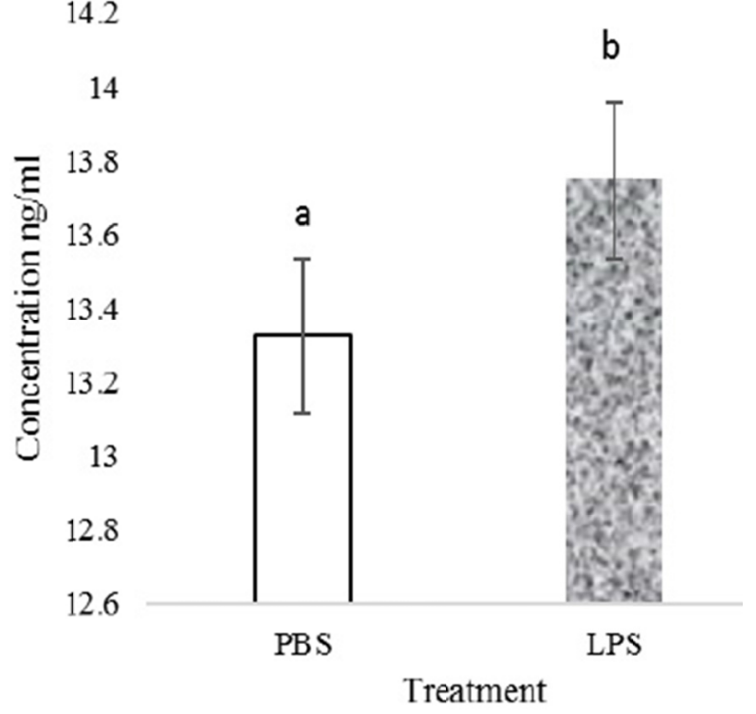

B)

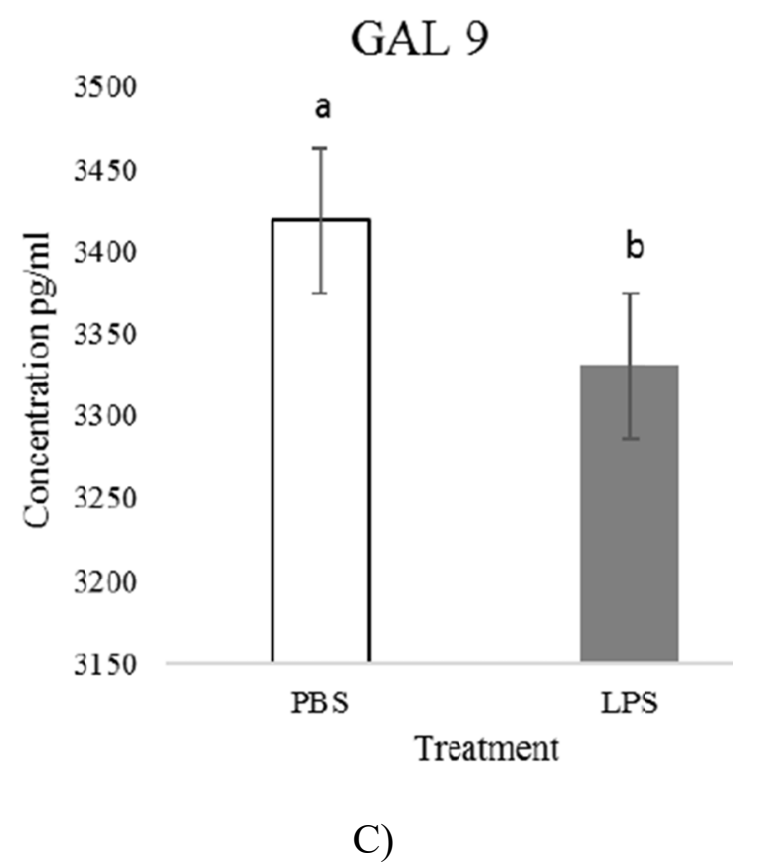

Figure 5. Effect of LPS treatment the concentrations of GAL-1, -3, and -9 measured in plasma

(A) GAL1, (B) GAL3, (C)GAL9. Means with the same letter are not significantly different from each other $(p<0.005)$. Error lines represent \pm standard deviation of the mean 


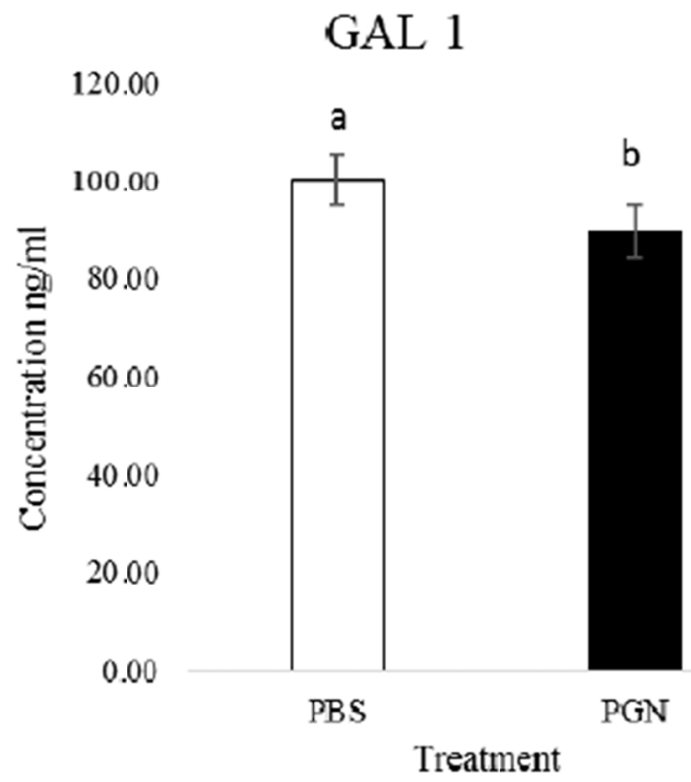

A)

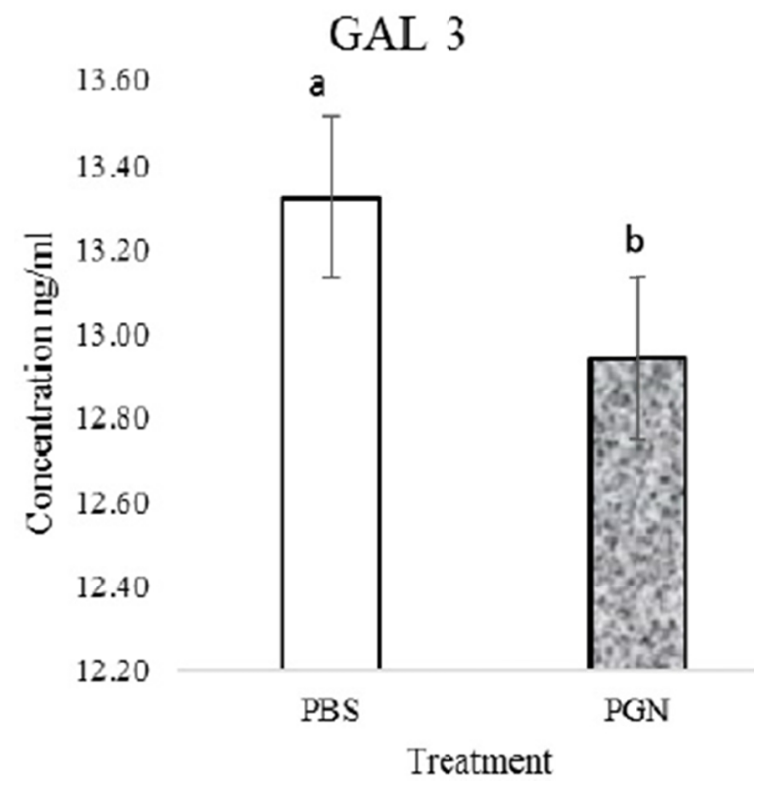

B)

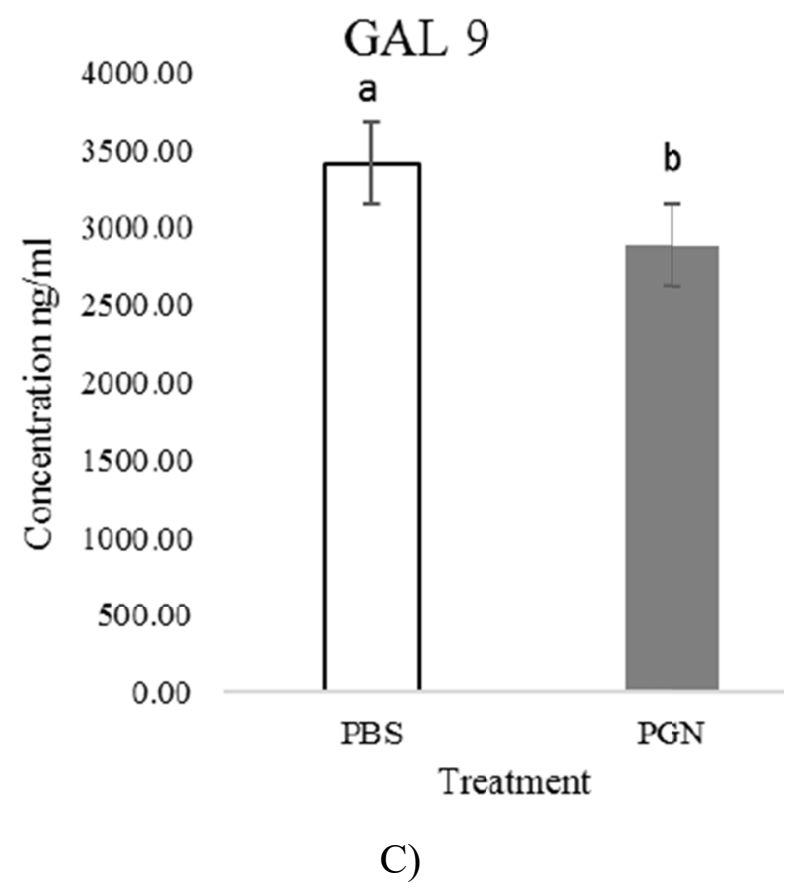

Figure 6. Effect of PGN treatment the concentrations of GAL-1, -3 , and -9 measured in plasma samples

A) GAL1, (B) GAL3, (C) GAL9. Means with the same letter are not significantly different from each other $(p<0.005)$. Error lines represent \pm standard deviation of the mean.

\section{Discussion}

The objective of the present study was to evaluate the effect of different PAMP's on galectin 
gene expression and secretion in goat blood. Innate immunity covers many areas of host defense against pathogenic microbes, including the recognition of PAMP's and DAMP's. Activation of the immune system by PAMP's and DAMP's is beneficial and helps the organism to recruit all its resources to fight the invading pathogen in the right time and place. Some of these PAMPs include LPS, PGN, poly I:C (viral DNA) and CpG ODN. It has been revealed that innate immunity can recognize conserved PAMPS through PRR's such as TLR's expressed on the cell surface of immune cells (Janeway Jr \& Medzhitov, 2002). Ten TLRs have been described to date in goats (Ekwemalor et al., 2016). They differ from each other in ligand specificities, expression patterns and target genes they induce. Specific features for the response to synthetic TLR agonist in goats have been tailored towards immunostimulation strategies. Neonatal goats produce much higher levels of Th1-type cytokines than adults in response to various TLR agonists. Recognition of invading pathogens triggers cytokine production and upregulation of costimulatory molecules in phagocytes, leading to activation of T-cells (Akira \& Hemmi, 2003). Studies have shown the ability of TLR's to activate and guide innate and adaptive immunity which can be exploited in the development of more effective immunotherapies and vaccination strategies for ruminants (Werling \& Coffey, 2007). Several TLRs are involved in recognition of variety PAMPS. They also interact with other receptors such as galectins. Galectins, a family of carbohydrate-binding proteins, control a variety of biological processes involved in activation, differentiation, trafficking and survival of immune cells (Allo, Toscano, Pinto, \& Rabinovich, 2018). They are stored and synthesized in the cytoplasm and may be secreted by inflammatory activated cells (Sato et al., 2009). Galectins play an important role in innate immunity by modulating effector cell function. Our study shows the expression and secretion of galectin genes as a result of modulation with different PAMPS.

Polyinosinic-polycytidylic acid is a synthetic analog of double-stranded RNA (dsRNA) widely used to analyze dsRNA-dependent cellular mechanisms. Treatment of cells with dsRNA in vitro mimics viral infection and regulates the expression of various genes. Studies have the shown the interaction between Poly (I:C) and galectin-9 (Katoh et al., 2014). Poly I:C serves as a PAMP associated with viral infection. Double-stranded RNA has been reported to elicit various cellular responses similar to those provoked by viral infection (Steer et al., 2003; Traynor, Majde, Bohnet, \& Krueger, 2004). They promote dendritic cell maturation and stimulation of both innate and adaptive immunity (Lin et al., 2012; West, Shadel, \& Ghosh, 2011). In our study treatment with poly I:C increased the secretion of GAL-1 and decreased the secretion of GAL-3 and -9. Also, our study showed the expression of galectins tested and their ligands as a result of treatment with poly I:C. Previous studies conducted by Ishikawa et al., (2014) reported an increase in the expression of LGAL-1 as a result of treatment with poly I:C. Previous studies have shown the interaction between viruses and LGAL-1 (Sato, Ouellet, StPierre, \& Tremblay, 2012; St-Pierre et al., 2011; M.-L. Yang et al., 2011). This result also corroborates with the result from our study which showed an increase in GAL-1 secretion. Galectin-1 is known to be involved in immunosuppressive and anti-inflammatory activities (Ishikawa et al., 2014). They also regulate immune responses such as T-cell homeostasis and survival, T-cell immune disorders, inflammation, and allergies as well as host-pathogen interactions (Rabinovich, Toscano, Jackson, \& Vasta, 2007). Studies have the shown the 
interaction between Poly I:C and LGAL-9 (Ishikawa et al., 2004; Katoh et al., 2014). Previous studies by (Ishikawa et al., 2004) showed that poly I:C upregulates the expression of LGAL-9 in the vascular endothelium. In contrast to our study, treatment with poly I:C downregulated the expression of LGAL-9. Previous studies conducted by (Dapat et al., 2017)) showed augmentation of GAL-9 levels in the supernatant, reduction of GAL-9 levels in the cells and decreased expression of LGAL-9 mRNA in response to viral infection. Studies have also recognized poly I:C as a potent immunostimulant candidate for a vaccine against pathogens (Barchet, Wimmenauer, Schlee, \& Hartmann, 2008; Hafner, Corthésy, \& Merkle, 2013). Some of these results correspond to our findings thereby suggesting their role during viral infection and as a potential DAMP.

CpG ODN's are short synthetic single-stranded DNA molecules containing unmethylated CpG dinucleotides in particular sequence contexts. CpG ODN's possess a partially or completely phosphorothioated (PS) backbone, as opposed to the natural phosphodiester (PO) backbone found in genomic bacterial DNA. In vaccine trials against bacterial infections, viral infections, and parasitic infections, CpG-ODN's have shown the ability to increase both innate immune responses and protective immunity (Davis et al., 1998; Decker et al., 2000) Previous studies have reported that $\mathrm{CpG}$ motifs triggers innate immune response through TLR-9 and induces the secretion of proinflammatory cytokines and activation of immune cells (Krieg, 2002; Trinchieri, 2003). CpG motifs have been used as adjuvants in many systems to enhance the immunogenicity of a vaccine or to skew the immune response from Th2 to Th1 (Ivory, Keller, $\&$ Chadee, 2006). Studies have also reported the interaction of CpG ODN with galectin-9 (Hayen et al., 2018; Kadowaki et al., 2012). In our study, treatment with ODN 2216 increased the secretion of GAL-1 and decreased the secretion of GAL-3 and -9. Treatment with ODN 2006 increased the secretion of GAL-3 and decreased the secretion of GAL-1 and -9. Both treatments decreased the secretion of GAL-9. Also, our study showed the expression of galectins and their ligands that were tested as a result of treatment. Previous studies have shown the effect of ODN on the expression of galectin genes (Osei, 2017). In our study, ODN 2216 and 2006 modulated the expression of LGAL-2, LGAL-7, and LGAL-14 which corroborates with previous findings. Also, previous research by (Hayen et al., 2018) showed an increase in the expression of LGAL-9 when intestinal epithelial cells were exposed to CpG. By contrast, our study showed the downregulation in the expression of LGAL-9 when treated with both classes of CpG.

Lipopolysaccharide represents a major PAMP from the outer membrane of Gram-negative bacteria and has been referred to be an important risk factor of mastitis (Fermino et al., 2011; Schmitz, Pfaffl, Meyer, \& Bruckmaier, 2004). It is a potent immune activator closely associated with many infectious and inflammatory diseases (Y. Li et al., 2008). Lipopolysaccharides trigger numerous physiological immunostimulatory effects in mammalian organisms. Previous studies conducted by our research team has demonstrated LPS as a PAMP (E. K. Asiamah et al., 2016). In our study treatment with LPS increased the secretion of GAL-3 and decreased the secretion of GAL-1 and -9. Also, our study showed the expression of galectins and their ligands that were tested as a result of treatment. Different studies have established the interaction between galectins and LPS. Previous studies conducted by (Fermino et al., 2011; Y. Li et al., 2008; Rabinovich et al., 2002) has shown the modulation 
of LGAL-3 by LPS. They reported that galectin-3 plays an important role in inflammatory diseases caused by bacteria and their products. Galectin-3 is constitutively produced by macrophages in mice and directly binds to LPS. In our study, LPS modulated an increase in Gal-3 concentration which corroborates with previous studies. In our study, there was a decrease in expression in LGAL-3 and its binding protein LGAL-3 binding-protein. Galectin-1 has also been reported to interact with LPS. Previous studies conducted by (Ilarregui et al., 2009) reported the interaction between LGAL-1 and LPS. In our study treatment with LPS reduced the secretion and expression of GAL-1. Our results also show that LPS modulated the expression of LGAL-9 in goat blood. Studies have shown the interaction of LPS and LGAL-9 (Matsuura et al., 2009). These results corroborate with our study thereby suggesting the role of LPS during inflammation and immune response.

Peptidoglycan is a component of nearly all bacterial cell walls and has a variety of functions. It is a huge single molecule surrounding the cytoplasmic membrane, and as such it enables the cell envelope to resist the turgor resulting from the difference in composition between the cytoplasm and the external environment (Hsu, Meng, \& VanNieuwenhze, 2016; Turner, Vollmer, \& Foster, 2014). They interact with the host and are recognized by the immune system. Previous studies conducted by our research team has demonstrated PGN as a PAMP (E. K. Asiamah et al., 2016). Other studies also have reported the interaction of peptidoglycan and galectins (Sioud et al., 2010; Thurston et al., 2012). Bacterial virulence factors can influence galectin secretion and expression (Elmwall et al., 2017; Won et al., 2007) and thus can serve as a regulatory mechanism in infection and inflammation. In our study, treatment with PGN decreased the secretion of LGALS-1, -3 and -9 . Also, our study showed the expression of galectins and their ligands that were tested as a result of treatment. Previous studies have reported the interaction of PGN with galectins (Huang et al., 2018). (Bao, Shen, Zhou, Dong, \& Lin, 2013) reported an increase in the expression of galectin after treatment with PGN. This result corroborates with our study thereby suggesting the involvement of galectins in immune defense against pathogens.

\section{Conclusion}

This study has described the expression and secretion of galectins and their ligands in goat blood when treated with different PAMPS. There was a distinct pattern of galectin expression and secretion. The results from this study have shown that galectins are involved in the goat's response to pathogens in blood. Also, in goat blood galectins may function as DAMP that orchestrates innate immune responses alongside the PAMP system as alarmins. Differential modulation may give insight into the regulation of host immunity for the design of diagnostics and interventions such as vaccines, anti-microbial, and immunostimulants.

\section{Acknowledgments}

The authors are grateful to North Carolina Agricultural and Technical State University Small Ruminant Research Unit. Also will like to thank National Institute of Food and Agriculture Evans Allen funds: Project Improving Resistance and Resilience: The Role of Galectins in Periparturient Ruminants. No. NC.X-300-5-16-120-1. Thanks are also due to Gary Summers and Dr. Hamid Ismail for their assistance and technical support as well as members of the Genomic Diversity and Animal Biotechnology laboratory. 


\section{References}

Adjei-Fremah, S., Ekwemalor, K., Asiamah, E. K., Ismail, H., Ibrahim, S., \& Worku, M. (2018). Effect of probiotic supplementation on growth and global gene expression in dairy cows. Journal of Applied Animal Research, 46(1), 257-263.

Akira, S., \& Hemmi, H. (2003). Recognition of pathogen-associated molecular patterns by TLR family. Immunology letters, $\quad 85(2), \quad$ 85-95. https://doi.org/10.1016/S0165-2478(02)00228-6

Akira, S., Uematsu, S., \& Takeuchi, O. (2006). Pathogen recognition and innate immunity. Cell, 124(4), 783-801. https://doi.org/10.1016/j.cell.2006.02.015

Allo, V. C. M., Toscano, M. A., Pinto, N., \& Rabinovich, G. A. (2018). Galectins: Key Players at the Frontiers of Innate and Adaptive Immunity. Trends in Glycoscience and Glycotechnology, 30(172), SE97-SE107. https://doi.org/10.4052/tigg.1740.1SE

Ashraf, G. M., Mahmoud, M. M., \& Tabrez, S. (2018). Studies on immunological and degranulation properties of a galectin-1 purified from goat (Capra hircus) heart. International journal of biological macromolecules, $115, \quad 1183-1188$. https://doi.org/10.1016/j.ijbiomac.2018.04.136

Asiamah, E. K., Adjei-Fremah, S., Osei, B., Ekwemalor, K., \& Worku, M. (2016). An extract of Sericea Lespedeza modulates production of inflammatory markers in pathogen associated molecular pattern (PAMP) activated ruminant blood. Journal of Agricultural Science, 8(9), 1. https://doi.org/10.5539/jas.v8n9p1

Asiamah, E., Adjei-Fremah, S., Ekwemalor, K., Sordillo, L., \& Worku, M. (2018). Parity and Periparturient Period Affects Galectin Gene Expression in Holstein Cow Blood. Journal of Applied Biotechnology, 6(2), 20. doi: https://doi.org/10.5296/jab.v6i2.13017

Bao, Y., Shen, H., Zhou, H., Dong, Y., \& Lin, Z. (2013). A tandem-repeat galectin from blood clam Tegillarca granosa and its induced mRNA expression response against bacterial challenge. Genes \& Genomics, 35(6), 733-740. https://doi.org/10.1007/s13258-013-0123-3

Barchet, W., Wimmenauer, V., Schlee, M., \& Hartmann, G. (2008). Accessing the therapeutic potential of immunostimulatory nucleic acids. Current opinion in immunology, 20(4), 389-395. https://doi.org/10.1016/j.coi.2008.07.007

Bodjo, S. C., Nwankpa, N., Chitsungo, E., Koffi, Y. M., Couacy-Hymann, E., Diop, M., ... Diallo, A. (2018). Development and validation of an epitope-blocking ELISA using an anti-haemagglutinin monoclonal antibody for specific detection of antibodies in sheep and goat sera directed against peste des petits ruminants virus. Archives of virology, 1-12. https://doi.org/10.1007/s00705-018-3782-1

Chiariotti, L., Salvatore, P., Frunzio, R., \& Bruni, C. B. (2002). Galectin genes: regulation of expression. Glycoconjugate journal, $19(7-9), \quad$ 441-449. https://doi.org/10.1023/B:GLYC.0000014073.23096.3a

Contreras, A., Sierra, D., Sánchez, A., Corrales, J., Marco, J., Paape, M., \& Gonzalo, C. (2007). Mastitis in small ruminants. Small Ruminant Research, 68(1-2), 145-153. https://doi.org/10.1016/j.smallrumres.2006.09.011 
Cooper, D. N. (2002). Galectinomics: finding themes in complexity. Biochimica et Biophysica Acta (BBA)-General Subjects, 1572(2-3), 209-231. https://doi.org/10.1016/S0304-4165(02)00310-0

Dapat, I. C., Pascapurnama, D. N., Iwasaki, H., Labayo, H. K., Chagan-Yasutan, H., Egawa, S., \& Hattori, T. (2017). Secretion of galectin-9 as a damp during dengue virus infection in thp-1 cells. International journal of molecular sciences, 18(8), 1644. https://doi.org/10.3390/ijms18081644

Davis, H. L., Weeranta, R., Waldschmidt, T. J., Tygrett, L., Schorr, J., \& Krieg, A. M. (1998). CpG DNA is a potent enhancer of specific immunity in mice immunized with recombinant hepatitis B surface antigen. The Journal of Immunology, 160(2), 870-876.

Decker, T., Schneller, F., Kronschnabl, M., Dechow, T., Lipford, G. B., Wagner, H., \& Peschel, C. (2000). Immunostimulatory CpG-oligonucleotides induce functional high affinity IL-2 receptors on B-CLL cells: costimulation with IL-2 results in a highly immunogenic phenotype. $\quad$ Experimental hematology, $28(5), \quad$ 558-568. https://doi.org/10.1016/S0301-472X(00)00144-2

Deierborg, T., \& Burguillos, M. A. (2015). A new "sweet" ligand for Toll-like receptor 4. Oncotarget, 6(24), 19928. https://doi.org/10.18632/oncotarget.4562

Ekwemalor, K. (2015). The Effect of a Mushroom (Coriolus versicolor) Based Probiotic on Innate immunity in Goats Naturally Infected with Gastrointestinal Parasites. North Carolina Agricultural and Technical State University,

Ekwemalor, K., Adjei-Fremah, S., Asiamah, E., Eluka-Okoludoh, E., Osei, B., \& Worku, M. (2018). Systemic expression of galectin genes in periparturient goats. Small ruminant research. doi:https://doi.org/10.1016/j.smallrumres.2018.09.013

Ekwemalor, K., Adjei-Fremah, S., Asiamah, E., \& Worku, M. (2018). Molecular Genetics and Genome Biology of Goats.

Ekwemalor, K., Asiamah, E., Osei, B., Ismail, H., \& Worku, M. (2017). Evaluation of the Effect of Probiotic Administration on Gene Expression in Goat Blood. Journal of Molecular Biology Research, 7(1), 88.

Ekwemalor, K., Asiamah, E., Osei, B., Ismail, H., \& Worku, M. (2017). Evaluation of the Effect of Probiotic Administration on Gene Expression in Goat Blood. Journal of Molecular Biology Research, 7(1), 88. https://doi.org/10.5539/jmbr.v7n1p88

Ekwemalor, K., Asiamah, E., \& Worku, M. (2016). Effect of a mushroom (Coriolus versicolor) based probiotic on the expression of toll-like receptors and signal transduction in goat neutrophils. Journal of Molecular Biology Research, 6(1), 71. https://doi.org/10.5539/jmbr.v6n1p71

Elmwall, J., Kwiecinski, J., Na, M., Ali, A. A., Osla, V., Shaw, L., ... Bylund, J. (2017). Galectin-3 is a target for proteases involved in the virulence of Staphylococcus aureus. Infection and immunity, IAI. 00177-00117. https://doi.org/10.1128/IAI.00177-17

Fermino, M. L., Polli, C. D., Toledo, K. A., Liu, F.-T., Hsu, D. K., Roque-Barreira, M. C., ... Halbwachs-Mecarelli, L. (2011). LPS-induced galectin-3 oligomerization results in 
\begin{tabular}{llllll}
\hline enhancement of neutrophil activation. PloS one, 6(10), e26004. & .
\end{tabular} https://doi.org/10.1371/journal.pone.0026004

Gibbons, P., Love, D., Craig, T., \& Budke, C. (2016). Efficacy of treatment of elevated coccidial oocyst counts in goats using amprolium versus ponazuril. Veterinary parasitology, 218, 1-4. https://doi.org/10.1016/j.vetpar.2015.12.020

Hafner, A. M., Corthésy, B., \& Merkle, H. P. (2013). Particulate formulations for the delivery of poly (I: C) as vaccine adjuvant. Advanced drug delivery reviews, 65(10), 1386-1399. https://doi.org/10.1016/j.addr.2013.05.013

Hayen, S. M., Otten, H. G., Overbeek, S. A., Knulst, A. C., Garssen, J., \& Willemsen, L. E. (2018). Exposure of Intestinal Epithelial Cells to Short-and Long-Chain Fructo-Oligosaccharides and $\mathrm{CpG}$ Oligodeoxynucleotides Enhances Peanut-Specific T Helper 1 Polarization. Frontiers in Immunology, 9. https://doi.org/10.3389/fimmu.2018.00923

Hsu, Y.-P., Meng, X., \& VanNieuwenhze, M. (2016). Methods for visualization of peptidoglycan biosynthesis. In Methods in Microbiology (Vol. 43, pp. 3-48): Elsevier.

Huang, M., Zhou, T., Wu, Y., Fei, H., Wang, G., Li, Z., . . . Lv, Z. (2018). Characterisation and functional comparison of single-CRD and multidomain containing galectins CgGal-2 and CgGal-3 from oyster Crassostrea gigas. Fish \& shellfish immunology, 78, 238-247. https://doi.org/10.1016/j.fsi.2018.04.029

Ilarregui, J. M., Croci, D. O., Bianco, G. A., Toscano, M. A., Salatino, M., Vermeulen, M. E., ... Rabinovich, G. A. (2009). Tolerogenic signals delivered by dendritic cells to T cells through a galectin-1-driven immunoregulatory circuit involving interleukin 27 and interleukin 10. Nature immunology, 10(9), 981. https://doi.org/10.1038/ni.1772

Ishikawa, A., Imaizumi, T., Yoshida, H., Nishi, N., Nakamura, T., Hirashima, M., \& Satoh, K. (2004). Double-stranded RNA enhances the expression of galectin-9 in vascular endothelial $\begin{array}{lllll}\text { cells. Immunology and cell biology, } & 82(4), & 410 .\end{array}$ https://doi.org/10.1111/j.0818-9641.2004.01248.x

Ivory, C. P., Keller, K., \& Chadee, K. (2006). CpG-oligodeoxynucleotide is a potent adjuvant with an Entamoeba histolytica Gal-inhibitable lectin vaccine against amoebic liver abscess in gerbils. Infection and immunity, 74(1), 528-536. https://doi.org/10.1128/IAI.74.1.528-536.2006

Janeway Jr, C. A., \& Medzhitov, R. (2002). Innate immune recognition. Annual review of immunology, 20(1), 197-216. https://doi.org/10.1146/annurev.immunol.20.083001.084359

Jones, K. E., Patel, N. G., Levy, M. A., Storeygard, A., Balk, D., Gittleman, J. L., \& Daszak, P. (2008). Global trends in emerging infectious diseases. Nature, 451(7181), 990. https://doi.org/10.1038/nature06536

Kadowaki, T., Arikawa, T., Shinonaga, R., Oomizu, S., Inagawa, H., Soma, G., ... Hirashima, M. (2012). Galectin-9 signaling prolongs survival in murine lung-cancer by inducing macrophages to differentiate into plasmacytoid dendritic cell-like macrophages. Clinical immunology, 142(3), 296-307. https://doi.org/10.1016/j.clim.2011.11.006 
Kannaki, T., Shanmugam, M., \& Verma, P. (2011). Toll-like receptors and their role in animal reproduction. Animal reproduction science, 125(1-4), 1-12. https://doi.org/10.1016/j.anireprosci.2011.03.008

Katoh, S., Ikeda, M., Shimizu, H., Mouri, K., Obase, Y., Kobashi, Y., ... Oka, M. (2014). Increased levels of plasma galectin-9 in patients with influenza virus infection. The Tohoku journal of experimental medicine, 232(4), 263-267. https://doi.org/10.1620/tjem.232.263

Krieg, A. M. (2002). CpG motifs in bacterial DNA and their immune effects. Annual review of immunology, 20(1), 709-760. https://doi.org/10.1146/annurev.immunol.20.100301.064842

Li, R. W., Hou, Y., Li, C., \& Gasbarre, L. C. (2010). Localized complement activation in the development of protective immunity against Ostertagia ostertagi infections in cattle. Veterinary parasitology, 174(3-4), 247-256. https://doi.org/10.1016/j.vetpar.2010.08.037

Li, Y.-H., Zhou, W.-H., Tao, Y., Wang, S.-C., Jiang, Y.-L., Zhang, D., ... Du, M.-R. (2016). The Galectin-9/Tim-3 pathway is involved in the regulation of NK cell function at the maternal-fetal interface in early pregnancy. Cellular \& molecular immunology, 13(1), 73. https://doi.org/10.1038/cmi.2014.126

Li, Y., Komai-Koma, M., Gilchrist, D. S., Hsu, D. K., Liu, F.-T., Springall, T., \& Xu, D. (2008). Galectin-3 is a negative regulator of lipopolysaccharide-mediated inflammation. The Journal of Immunology, 181(4), 2781-2789. https://doi.org/10.4049/jimmunol.181.4.2781

Livak, K. J., \& Schmittgen, T. D. (2001). Analysis of relative gene expression data using real-time quantitative PCR and the 2- $\Delta \Delta \mathrm{CT}$ method. methods, 25(4), 402-408. https://doi.org/10.1006/meth.2001.1262

Matsuura, A., Tsukada, J., Mizobe, T., Higashi, T., Mouri, F., Tanikawa, R., ... Tanaka, Y. (2009). Intracellular galectin-9 activates inflammatory cytokines in monocytes. Genes to Cells, 14(4), 511-521. https://doi.org/10.1111/j.1365-2443.2009.01287.x

Osei, B. (2017). Evaluation of Galectin Gene Expression During the Periparturient Period and After Modulation in St. Croix Sheep. North Carolina Agricultural and Technical State University,

Pulendran, B. (2004). Modulating vaccine responses with dendritic cells and Toll-like $\begin{array}{llll}\text { receptors. } & \text { Immunological } & \text { 227-250. }\end{array}$ https://doi.org/10.1111/j.0105-2896.2004.00144.x

Rabinovich, G. A., Baum, L. G., Tinari, N., Paganelli, R., Natoli, C., Liu, F.-T., \& Iacobelli, S. (2002). Galectins and their ligands: amplifiers, silencers or tuners of the inflammatory response? Trends in immunology, 313-320. https://doi.org/10.1016/S1471-4906(02)02232-9

Rabinovich, G. A., \& Toscano, M. A. (2009). Turning'sweet'on immunity: galectin-glycan interactions in immune tolerance and inflammation. Nature Reviews Immunology, 9(5), 338. https://doi.org/10.1038/nri2536

Rabinovich, G. A., Toscano, M. A., Jackson, S. S., \& Vasta, G. R. (2007). Functions of cell surface galectin-glycoprotein lattices. Current opinion in structural biology, 17(5), 513-520. https://doi.org/10.1016/j.sbi.2007.09.002 
Rinaldi, L., Veneziano, V., \& Cringoli, G. (2007). Dairy goat production and the importance of gastrointestinal strongyle parasitism. Transactions of the Royal Society of Tropical Medicine and Hygiene, 101(8), 745-746. https://doi.org/10.1016/j.trstmh.2007.03.010

Sato, S., \& Nieminen, J. (2002). Seeing strangers or announcing "danger": galectin-3 in two models of innate immunity. Glycoconjugate journal, 19(7-9), 583-591. https://doi.org/10.1023/B:GLYC.0000014089.17121.cc

Sato, S., Ouellet, M., St-Pierre, C., \& Tremblay, M. J. (2012). Glycans, galectins, and HIV-1 infection. Annals of the New York Academy of Sciences, 1253(1), 133-148. https://doi.org/10.1111/j.1749-6632.2012.06475.x

Sato, S., St-Pierre, C., Bhaumik, P., \& Nieminen, J. (2009). Galectins in innate immunity: dual functions of host soluble $\beta$-galactoside-binding lectins as damage-associated molecular patterns (DAMPs) and as receptors for pathogen-associated molecular patterns (PAMPs). Immunological reviews, 230(1), 172-187. https://doi.org/10.1111/j.1600-065X.2009.00790.X

Schmitz, S., Pfaffl, M., Meyer, H., \& Bruckmaier, R. (2004). Short-term changes of mRNA expression of various inflammatory factors and milk proteins in mammary tissue during LPS-induced mastitis. Domestic animal endocrinology, 26(2), 111-126. https://doi.org/10.1016/j.domaniend.2003.09.003

Sioud, M., Mobergslien, A., Boudabous, A., \& Fløisand, Y. (2010). Evidence for the involvement of galectin-3 in mesenchymal stem cell suppression of allogeneic T-cell proliferation. Scandinavian journal of immunology, 71(4), 267-274. https://doi.org/10.1111/j.1365-3083.2010.02378.x

Souza, B. M., Lambert, S. M., Nishi, S. M., Saldaña, G. F., Oliveira, G. G., Vieira, L. S., ... Almeida, M. A. O. (2018). Collectins and galectins in the abomasum of goats susceptible and resistant to gastrointestinal nematode infection. Veterinary Parasitology: Regional Studies and Reports, 12, 99-105.

St-Pierre, C., Manya, H., Ouellet, M., Clark, G. F., Endo, T., Tremblay, M. J., \& Sato, S. (2011). Host soluble galectin-1 promotes HIV-1 replication through a direct interaction with glycans of viral gp120 and host CD4. Journal of virology, JVI. 05351-05311. https://doi.org/10.1128/JVI.05351-11

Steer, S. A., Moran, J. M., Maggi, L. B., Buller, R. M. L., Perlman, H., \& Corbett, J. A. (2003). Regulation of cyclooxygenase-2 expression by macrophages in response to double-stranded RNA and viral infection. The Journal of Immunology, 170(2), 1070-1076. https://doi.org/10.4049/jimmunol.170.2.1070

Sun, Y., Johnson, C., Zhou, J., Wang, L., Li, Y.-F., Lu, Y., ... Sanchez, C. (2018). Uremic toxins are conditional danger-or homeostasis-associated molecular patterns. Frontiers in bioscience (Landmark edition), 23, 348-387. https://doi.org/10.2741/4595

Thurston, T. L., Wandel, M. P., von Muhlinen, N., Foeglein, Á., \& Randow, F. (2012). Galectin 8 targets damaged vesicles for autophagy to defend cells against bacterial invasion. Nature, 482(7385), 414. https://doi.org/10.1038/nature10744

Tourais-Esteves, I., Bernardet, N., Lacroix-Lamandé, S., Ferret-Bernard, S., \& Laurent, F. (2008). Neonatal goats display a stronger TH1-type cytokine response to TLR ligands than 
adults. Developmental \& Comparative Immunology, 32(10), 1231-1241. https://doi.org/10.1016/j.dci.2008.03.011

Traynor, T. R., Majde, J. A., Bohnet, S. G., \& Krueger, J. M. (2004). Intratracheal double-stranded RNA plus interferon- $\gamma$ : a model for analysis of the acute phase response to respiratory viral infections. Life sciences, 74(20), 2563-2576. https://doi.org/10.1016/j.1fs.2003.10.010

Trinchieri, G. (2003). Interleukin-12 and the regulation of innate resistance and adaptive immunity. Nature Reviews Immunology, 3(2), 133. https://doi.org/10.1038/nri1001

Turner, R. D., Vollmer, W., \& Foster, S. J. (2014). Different walls for rods and balls: the diversity of peptidoglycan. Molecular microbiology, 91(5), 862-874. https://doi.org/10.1111/mmi.12513

Vasta, G. R. (2012). Galectins as pattern recognition receptors: structure, function, and evolution. In Current Topics in Innate Immunity II (pp. 21-36): Springer. https://doi.org/10.1007/978-1-4614-0106-3_2

Werling, D., \& Coffey, T. J. (2007). Pattern recognition receptors in companion and farm animals-The key to unlocking the door to animal disease? The Veterinary Journal, 174(2), 240-251. https://doi.org/10.1016/j.tvj1.2006.10.010

Werling, D., Piercy, J., \& Coffey, T. J. (2006). Expression of TOLL-like receptors (TLR) by bovine antigen-presenting cells-Potential role in pathogen discrimination? Veterinary immunology and immunopathology, $\quad$ 112(1-2), https://doi.org/10.1016/j.vetimm.2006.03.007

Won, Y.-S., Jeong, E.-S., Park, H.-J., Lee, C.-H., Nam, K.-H., Kim, H.-C., ... Choi, Y.-K. (2007). Upregulation of galectin-3 by Corynebacterium kutscheri infection in the rat lung. Experimental animals, 56(2), 85-91. https://doi.org/10.1538/expanim.56.85

Yang, M.-L., Chen, Y.-H., Wang, S.-W., Huang, Y.-J., Leu, C.-H., Yeh, N.-C., ... Chen, Y.-L. (2011). Galectin-1 Binds to Influenza Virus and Ameliorates Influenza Pathogenesis. Journal of virology, JVI. 00301-00311. https://doi.org/10.1128/JVI.00301-11

Yang, X.-F., Yin, Y., \& Wang, H. (2008). Vascular inflammation and atherogenesis are activated via receptors for PAMPs and suppressed by regulatory T cells. Drug Discovery Today: Therapeutic Strategies, 5(2), 125-142. https://doi.org/10.1016/j.ddstr.2008.11.003

Zhu, C., Anderson, A. C., Schubart, A., Xiong, H., Imitola, J., Khoury, S. J., ... Kuchroo, V. K. (2005). The Tim-3 ligand galectin-9 negatively regulates $\mathrm{T}$ helper type 1 immunity. Nature immunology, 6(12), 1245. https://doi.org/10.1038/ni1271

\section{Copyright Disclaimer}

Copyright reserved by the author(s).

This article is an open-access article distributed under the terms and conditions of the Creative Commons Attribution license (http://creativecommons.org/licenses/by/3.0/). 